UDC 349.6

DOI https://doi.org/10.37687/2413-7189.2020.3.10

\author{
Sydor V.D., \\ Doctor of Law, Professor, \\ Professor at the Department of Constitutional, \\ Administrative and International Law \\ Kyiv Institute of Intellectual Property and Law \\ of the National University "Odesa Law Academy" \\ ORCID: 0000-0002-1794-2577
}

\author{
Kostytska I.O., \\ Doctor of Law Sciences, Senior Researcher, \\ Institute of Legislation of the Verkhovna Rada of Ukraine \\ ORCID: 0000-0003-2336-1426
}

\title{
THE CLASSICAL AND MODERN APPROACHES TO ENVIRONMENTAL LAW RESEARCHES
}

\section{КЛАСИЧНІ ТА СУЧАСНІ ПІДХОДИ ДО ДОСЛІДЖЕННЯ ЕКОЛОГІЧНОГО ПРАВА}

The paper is devoted to comprehensive and detailed study of the classical and modern approaches to environmental law researches. The author substantiates that environmental legislation as a specific regulation tool significantly affects the selection of means and methods used in the process of regulating environmental relations. The system of approaches and methods in environmental law and legislation is analized. It is established that for modern research the use of classical methods, such as: formal-logical method, dogmatic method, method of factor analysis, functional-legal method, comparative-legal method, sociological method, historical-legal method, system-structural method, logic-semantic method, prognostic method are insufficient. The paper emphasizes on such an important methodological feature of the study of the environmental law as the usage of an interdisciplinary approach. The article argues that environmental relations should be studied in accordance with the laws of self-organization and self-development. They have a historical status, stages of growth and development, periods of stability and change. The historical status of ecological relations helps to determine the specifics of different stages of formation and functioning, as their development depends on the stages of social development. We reasonably believe that the spread of synergy as an interdisciplinary method of research marked the transition to the postclassical development of the science of environmental law. It is proposed to design a new methodological strategy based on co-evolutionary relationship between human and nature, anthropology, synergy and other modern sciences. Main legal factors of the environmental legislation effectiveness are investigated. The authors proves that various defects of the environmental laws reduce their effectiveness.

Key words: environmental law, research, methodology, methodological approaches, classical methods, modern methods, interdisciplinary approaches.

Стаття присвячена всебічному та детальному вивченню класичних і сучасних методологічних підходів до дослідження екологічного права. Динаміка розвитку екологічних відносин суспільства стикає науку про екологічне право з багатьма проблемами. Швидкі реформи економічної та політичної системи Украӥни, значне динамічне формування нових форм суспільного життя вимагають відповідного правового забезпечення, яке базувалося б на сучасній науковій теорї та методології. Автори обтрунтовують, щзо екологічне законодавство як специффічний інструмент регулювання суттєво впливає на вибір засобів і методів, щчо використовуються у процесі регулювання екологічних відносин. У публікаџї̈ проведено комплексний аналіз системи класичних та новітніх підходів та методів дослідження еколого-правових явищ. У результаті авторами встановлено, щьо для проведення сучасних досліджень використання класичних методів, таких як: формально-логічний метод, догматичний метод, метод факторного аналізу, функціонально-правовий метод, порівняльно-правовий метод, соціологічний метод, історико-правовий метод, системно-структурний метод, логіко-семантичний метод, прогностичний метод - на сьогодні вже є недостатніми. У науковій статті авторами наголошується на такій важливій методологічній особливості вивчення екологічного законодавства, як використання міждисциплінарного підходу. Обстоюється думка, щзо в даний час існує об'єктивна необхідність комплексного, системного підходу до проведення еколого-правових досліджень. У статті доводиться думка, щьо екологічні відносини слід досліджувати відповідно до законів самоорганізаиї та саморозвитку. Вони мають історичний статус, етапи зростання та розвитку, періоди стабільності та змін. Встановлено, щзо історичний статус екологічних відносин допомагає визначити специфіку різних етапів становлення та функціонування, оскільки їх розвиток залежить від стадій соиіального розвитку. Обтрунтовано ідею, щчо поширення синергї як міждисциплінарного методу дослідження ознаменувало перехід до посткласичного розвитку науки екологічного права. Запропоновано розробити нову методологічну стратегію, засновану на коеволюиійних відносинах між людиною та природою, антропології, синергії та інших 
сучасних науках. У публікачії досліджено основні правові фактори ефективності екологічного законодавства. Автори доводять, щчо різні дефекти екологічного законодавства знижують їх ефективність та провокують правоохоронні помилки, які часто виражаються в порушенні екологічних прав.

Ключові слова: екологічне право, дослідження, методологія, методологічні підходи, класичні методи, сучасні методи, міждисциплінарні підходи.

Introduction. The dynamics of the development of the environmental relations of the society confronts the science of environmental law with many problems. The destruction of the economic and socio-political system of the Soviet society led to a certain disruption in the research of the methodology of social processes. Rapid reforms of the economic and political system of Ukraine, significant dynamic formation of the new forms of social life require appropriate legal provision that would be based on the modern scientific theory and methodology.

The state of scientific research of the problem. The analysis of the scientific literature reveals the different, often contradictory approaches to the interpretation of both the concept and the essence of the methodology and it characteristics, features and developmental trends in the science of environmental law. It can be explained by the diversity of methodological investigations that differ by their theoretical level, the degree of differentiation of their own methodological problems from the object of its study, and by the author's understanding of the basic methodological research methods and techniques of environmental-legal phenomena. There is a general opinion in legal literature that the methodology of science should be considered as the study of general principles, ways, patterns of scientific knowledge, principles and practices that are carried out at different levels (philosophical, scientific, specific sciences, methods and techniques). They aim at development of the provisions that give the opportunity to choose tools and to build procedures which will effectively resolve problems and challenges that arise in the process of research. The methodology defines the means of gaining scientific knowledge, which reflects the dynamic processes and phenomena, provides comprehensiveness of information, creates a system of legal information that is based on objective facts.

The purpose of the article is to outline the main traditional and modern methodological approaches to environmental law research in order to establish the most effective ones.

Main body. Environmental methodology contains knowledge about: 1) approaches, principles, methods and techniques which are to be used in studying the sources of law; 2) approaches, principles, methods and techniques of knowledge which should be used in any experimental procedure; 3 ) the content of specific approaches, principles, methods and techniques used for the law sources and the consequences of their development; 4) the way the methods are interrelated in the process of learning and obtaining new knowledge.

The methodology of the legal science is a system of approaches, methods and techniques of the scientific research, the theoretical basis of their usage in the study of the state-legal phenomena.

The basis of the methodology of legal science is presented by such approaches: 1) philosophical and ideological approaches (materialistic or idealistic, metaphysical or dialectical, recognition or denial of the objective social, including state-legal, patterns and possibilities of their studying and gaining true knowledge about them); 2) general scientific methods, that are used in all or most sciences (structural, functional methods, method of transition from the abstract to the concrete); 3) formal logical procedures - analysis and synthesis; 4) group methods that are used only in a particular group of sciences, for example, only in the social sciences (e.g., method of concrete sociological research); 5) special methods that are appropriate for the study of any science subject (interpretation of the legal norms, special techniques summarizing legal practice) [1, p. 618].

Methodology is objectively determined by the subject knowledge derived from general conceptual approaches, the level of the scientific knowledge. The methodology is a system of methods, a set of techniquess and activities of research and knowledge about them. Objectively, this system is stipulated by the nature of the phenomena and processes which are studied and which arise from the general methodological state of thescientific knowledge and scientific interests.

A comprehensive and detailed study of the methodological problems of environmental legislation development should be one of the main tasks of the science of environmental law. Methodology of environmental laws is an application of a set of specific theoretical principles, logical and special methods of investigation of the environmental legislation development [2, p. 14]. The method of study is a mind process that is implemented in a scientific manner and focused on the subject (object) of the research to acquire new legal knowledge in general theoretical and in applied aspects of the study.

There are main methods of scientific research in environmental law: 1) formal logical method that provides scientific reliability of the obtained information and enables to detect inconsistency of certain environmental laws with the realities of social life, as well as contradictions between some norm-legislative acts; 2) formal legal method that guarantees the study of environmental law development problems exclusively in the context of positivism; 3) method of factor analysis, which allows to take into account quantitative and qualitative changes in environmental laws depending on certain circumstances, and also to build factor models needed in the process of legal forecasting; 4) functional legal 
method which requires the study of environmental law from the standpoint of its tasks and functions; 5) activity method that helps to examine the role, place and meaning of a single norm-legislative act in the environmental legislation; 6) comparative legal method which facilitates the identification of general and special, typical and unique characteristics in the legal regulation of the environmental relations in different countries. It allows establishing a positive experience of legal regulation of environmental relations abroad; 7) sociological method which enables to study and consider the general laws of social development, economic analysis, political, social, psychological, demographic and other phenomena in the society in the process of developing regulations of the environmental laws; 8) historical and legal method that provides succession of environmental laws development, allows to reveal the positive and negative features of historical sources of environmental laws and helps to establish the consequences of their impact on the environmental relations; 9) systematic and structural method that allows to regard the environmental legislation as an orderly, coherent, logically structured set of normlegislative acts aimed at regulating land relations; 10) logical-semantic method based on tracing the formation of specific conceptual-categorical system of the environmental laws; 11) prognostic method that makes it possible to make science-based forecasts of the environmental laws development. Formal-logical method is one of the most traditional ones in the legal science [3, p. 38].

Future law science seems primarily responsible for studying two basic fundamental key problems: the methodology of law and cooperation with other natural, technical and social sciences. It's time to finally understand that the content of the development of methodological law problems doesn't only involve self-understanding of the science, the improvement of the legal culture of thinking, but it also gives the future research powerful cognitive tools that allow to deeply penetrate into the unknown, not yet investigated layers of the legal reality. An important methodological feature of the study of the environmental law is the usage of an interdisciplinary approach. The Environmental law as a science is a structured knowledge of the environmental norms, forms and methods of forming the environmental law awareness and ways to improve it. It also includes: legislators' ideas about the subject and method of the given branch of legal knowledge, sources and determinants of their formation, the place of environmental law in the jurisprudence.

The essential point that determines the nature and characteristics of the formation and development of the environmental legal knowledge is the awareness of the connection of environmental rights, not only with other branches of legal science, but also with other social sciences - sociology and philosophy that define the methodological research. In particular, the philosophical part is not only an external means of theoretical justification, but it also determines the methodological orientations and inner meaning of most theoretical concepts and the knowledge. National and foreign philosophical, economical, environmental, agricultural, biological and other doctrines, as well as the legal doctrine of the environmental usage are the basis for the economic, social, public legal, demographic, spiritual and cultural development of the people and conservation of the environment. In the relationship people - nature an exclusive role belongs to the environmental as an object of legal regulation of social relations are caused by its objective physical characteristics and functions in nature, economy, society, and the subjective legal qualities that define it as an object of environmental land law.

Environmental relations develop on the basis of the economic consequences, and the environmental laws influence their formation and development. While regulating with the help of the developed norms of the environmental legislation, the reverse process of transferring regulatory requirements into an actual behavior and into real social environmental relations.

Updating of the problems of using sociological approach in environmental law science is stipulated by the role of this area of law in theory and practice of state functioning. One of the real ways to overcome the crisis in modern jurisprudence is the development of the sociology of the law, the study of law as a phenomenon of our civilization through the prism of "life", abstract legal norms due to its application, fulfillment and realization by the subjects of the social relations. Environmental legislation as a specific regulation tool significantly affects the selection of means and methods used in the process of regulating environmental relations.

In a legal state the legislative activity involves correspondence between legality and law expediency taken on behalf of the state organized society. They necessarily take into account the interests of each individual, which are implemented by all legal entities and primarily by the state itself. Since the law as a whole is intended to assist the legislator in the development of scientific bases of society and sciencebased recommendations for the improvement of this administration, it can be argued that the task of legal science is to assist the legislator in the formulation and adoption of legal norms.

Nowadays environmental law is developing rapidly and the science of the environmental law should aim at facilitating this process by solving current and future problems of improving the environmental legislation. The social function of the legal science require scientists to develop effective mechanisms that can influence the situation in law enforcement. In order to adequately respond to the current need for integrated research of analytical and applied nature, it is necessary to turn theoretical understanding into the generalization of the social and judicial practices, considering the legislative dynamics and changing economic and political conditions. 
This approach does not reduce the importance of the fundamental works. It primarily deals with the fundamental nature of the legal science, the attempt to close the gap between theory and practice. The Environmental law today is experiencing a period of the accumulation of the theoretical knowledge, but its isolation from the needs of the legal and social life may have negative consequences for the entire industry. Legislative activity is based on the needs of objective, independent from the people's will economic laws. Implementing the unification of the old and developing the new environmental legislation is necessary to take into account the objective nature of the economic laws, correlation between economic and legal laws question which leads to the subjective idealism.

The current level of the environmental law science and legislative activity poses before the science of the environmental law the problem of improving the methods of the empirical research in the field of environmental law norms application with the goal to identify their efficiency and find ways to improve environmental legislation, bringing it in compliance with the changing socio-economic conditions of our society. In this regard, considerable importance is attached to the sociological trend in land environmental science, which involves the study of actual social relations in environmental law, analysis of the relationship between legal norms, legal relationship and actual environmental relations. In particular, the methods of empirical research in environmental law represent surveys and questionnaires of environmental law specialists, observation method, etc.

The socialization of the law and legal knowledge has become one of the most important directions of adapting domestic law to the current challenges. The man as a carrier of inalienable rights and freedoms, which have to determine the content and direction of the state functioning, can now be seen outside the legal science [5, p. 138]. Only with awareness of the social foundations of rights, the legislation may be considered in the context of ensuring and protecting the rights and freedoms of a man and a citizen, functioning of a legal state and a legal culture. On this basis the sociological approach to a law as a theoretical concept that has social nature, different from the usual application of the jurisprudence methods of empirical sociological research to confirm certain theoretical conclusions, is formed. It is necessary to conduct in-depth analysis of the existing environmental relations which require or may require the legislative regulation. Since actual social relations are rather interchangeable, unstable, it is important not only to identify their current system, but also to find out the trends of their development. This analysis makes it possible to build a model of legal regulation of relations in the future, or, in other words, to predict the development of the environmental law, to prepare the creation of appropriate norms and institutions.
The main peculiarity of a legal prediction is the recognition of the fact that the law is always evolving to reflect changes in social life, in actual people's relations. It is possible to predict the development of law only on the basis of known or projected society development. However, the prognostic nature of the reflection in the law has its limits which can be divided into social, epistemological and the legislative rights themselves.

Social boundaries are expressed in the fact that the legislation should not only accurately reflect the future development of social relations, but also take into consideration a real social, specific historical opportunity to achieve it. Socio-legal prediction can be fruitful only when it is based on the study of the general laws of the social development. It is necessary to analyze the economic, political, social, psychological, demographic and other phenomena in society, which together determine the possibility of a public life regulation to reveal the objective laws of these phenomena [6, p. 87].

The fundamental methodological problem of environmental law and legislation is the subjective factor and the complexity of legislators' understanding of the legal environmental processes and phenomena. A man creates legislation that would adjust environmental relations, and it seems that the existence of this law depends on the will of a person who has made it. However, the trajectory of environmental legislation often goes beyond the goals and objectives of its creators. The environmental law science is beginning to use synergy methodology, a new science that studies self-organizing, random processes. These methodological ideas allow a better understanding of the genesis of the environmental legislation, some of its legal institutions.

Environmental relations are to be investigated according to the laws of self-organization and self-development. They have a historic status, stages of growth and development, periods of stability and change. Historical status of the environmental relations helps determine the specificity of different stages of formation and functioning because their development depends on the stages of the social development. The spread of synergy as an interdisciplinary research method marked the transition to Post-classical development of the science.

Synergetics explores various open systems capable of selfdevelopment. This system is estimated as a nonlinear, characterized by a special mechanism of bifurcations, irreversibility and uncertainty. Random fluctuations imbalance the system and as a result, it loses its stability. Due to the positive feedback, the fluctuations are increasingly amplified and can lead to bifurcation the destruction of the previous system and its transition to a new state. Switching to a higher stage means self-organization. Instability is no longer considered as something destructive and negative; it is regarded as a condition of stable and dynamic development. The emergence and development of the idea of the imbalance, non-linearity and instability proved multivariate ways of 
development [7, p. 13]. As a result, modern system of thinking is more likely to take into account the dynamics in the study of stability problems. Synergetic understanding of the development and structure represents a new stage of methodology.

Productivity of synergy ideas is the synthesis of the subjective and objective approaches. The role of synergy provokes internal growth, self-organization of the environmental and legal knowledge, its inner reorganization. New information about the constructive role of a chance in a social development allows to clarify the subjective factor of reforms, and to take into account both logical cause-effect relations and random relations. Possibilities of synergy are extremely broad in the study of legal processes. Synergistic methodology is relevant due to the increase of the number of the regulations, widening of the range of their action and consolidation of them with the disparate, sometimes contradictory public interests. Synergistic methodology develops the concept of selforganization rights, emphasizing the growing danger of the disruption. It points out the cause of unpredictable reactions of subjects in their legal relationship. Synergetic approach allows us to take a fresh look at the issues of overcoming and eliminating inconsistencies in the regulations and other legal acts. The research is driven largely by the structural and systemic approach. The specificity of synergetic approach lies in its completion by a large unit that examines patterns of inconsistency of the law. In addition, scientific approach using synergy ideas enables us to master qualitatively a new group of methods and principles of the research.

Synergistic research approach to legal theory leads to the conclusion that the synergistic ideas can help "uncover" significant resources for improving the efficiency of the regulation without any special costs and, what it is important, to minimize the costs of limited legal means and methods. On the way of the promotion of new ideas in law, the legal science should reject the domination of the monistic law comprehension. Its roots are so deep that many researchers ignore the fact, and some directly deny any other spheres of law life except legal norms based on the traditions of "pure" law. This leads to a conclusion about the excellency of the standards established by the legislator, where judgments are made within the space, limited by the regulatory forms $[8$, p. 168].

The necessity of transcending law dogma and consideration of its other faces and forms of existence is dictated by the objective needs of the environmental law as a branch of law, and as a science. This dogmatic approach is not rejected, but it must be used in the combination with other approaches, such as natural, social and others. Only then environmental legislation will be available for public understanding as a regulator of environmental relations.

The value of the current environmental law and its highest purpose is to create conditions for the realization of the natural and inalienable environmental rights. Environmental issues should be investigated according to the laws of selforganization and self-development. They have historic status, stages of growth and development, periods of stability and change. Historical status of environmental relations helps determine the specificity of different stages of formation and functioning, because their development depends on the stages of social development.

Conclusions. At present time there is an objective need for a comprehensive, systematic approach to the legal institution of the monitoring of the environmental legislation. Monitoring in the field of the environmental legislation is an innovative institution of governance and the development of the civil society. Based on the synthesis and analysis of its results the decisions in the sphere of environmental relations can be developed promptly, efficiently and effectively implemented. The establishment of a system for monitoring of the environmental laws is a necessary tool to ensure a proper quality of the government decisions on the basis of the development and consolidation of the experience that is already in the monitoring legislation. The creation and development of its new branch forms should be aimed to ensure the development and adoption of the common decisions by the legislative and executive powers in the process of the legislative activity.

\section{References:}

1. Юридична енциклопедія : В 6 т. / Редкол. : Ю.С. Шемшученко (голова редкол.) та ін. / 3-й том «К-М». Київ : Укр. енцикл., 2001. С. 618.

2. Гетьман А. Методологічні засади становлення правових основ охорони довкілля. Право України. 2011. № 2. С. 14.

3. Пархоменко Н.М. Джерела права: проблеми теорії та методології : монографія. Київ : ТОВ «Вид-во «Юрид. думка», 2008. С. 38.

4. Малишева Н.Р. Гармонізація екологічного законодавства в Свропі : дис. у формі наук. доповіді на здобуття наук. ступеня д-ра юрид. наук ; Ін-т держави і права ім. В.М. Корецького НАН України. Київ, 1996. С. 18.

5. Петришин О. Проблеми соціалізації права та соціологізації правової науки. Право України. 2011. № 8. С. 138.

6. Костицький В.В. Соціологія права: науково-теоретична спадщина Євгена Ерліха і проблеми розвитку сучасної науки : монографія. Ін-т законодав. передбачень і прав. експертизи. Вид. 2-ге. Київ : Коло, 2016. С. 87.

7. Князева Е.Н. Синергетика: начала нелинейного мышления. Общественные науки и современность. 1993. № 2. C. 13.

8. Сидор В.Д. Методологічні основи земельного законодавства України. Наукові записки Львівського університету бізнесу та права. Львів : ЛУБП, 2010. Вип. 5. С. 168. 